\title{
THE TRANSNATIONAL EDUCATION TO EMPLOYMENT TRANSITION: PERUVIAN WOMEN AND MEN PROFESSIONAL AND FAMILY TRAJECTORIES IN SWITZERLAND
}

\author{
Presses Universitaires de France | «Journal of international Mobility »
}

$2018 / 1 \mathrm{~N}^{\circ} 6$ | pages 191 à 210

ISSN 2296-5165

ISBN 9782130803270

Article disponible en ligne à l'adresse :

https://www.cairn.info/revue-journal-of-international-mobility-2018-1-page-191.htm

Distribution électronique Cairn.info pour Presses Universitaires de France.

(C) Presses Universitaires de France. Tous droits réservés pour tous pays.

La reproduction ou représentation de cet article, notamment par photocopie, n'est autorisée que dans les limites des conditions générales d'utilisation du site ou, le cas échéant, des conditions générales de la licence souscrite par votre établissement. Toute autre reproduction ou représentation, en tout ou partie, sous quelque forme et de quelque manière que ce soit, est interdite sauf accord préalable et écrit de l'éditeur, en dehors des cas prévus par la législation en vigueur en France. Il est précisé que son stockage dans une base de données est également interdit. 


\title{
The transnational education to employment transition: Peruvian women and men professional and family trajectories in Switzerland.
}

\author{
Romina Seminario *
}

\begin{abstract}
Drawing on a life-course perspective, this paper focuses on the analysis of the transnational education to employment transitions that particularly shows the interdependence of professional and family trajectories in a migration context. I focus on Peruvian migration to study in a Swiss Higher Education institution and subsequent job-hunting in the Swiss labour market; and link them with transnational family configurations. I present two types of life-courses found among highly skilled Peruvian men and women: the concordance or discordance between education credentials and current employment conditions. Although many studies have emphasised the problems of validating foreign degrees as the greatest barrier for highly skilled foreigners, I argue that having a Swiss degree does not automatically guarantee adequate employment for Peruvian men and women in Switzerland. The findings clearly stress the ambivalent role of Swiss degrees for migrants, as well as, the heterogeneous impact of partnership and parenthood. These processes can be explained by different opportunities and limitations based on fields of qualification and dynamic gender normativity in couple's negotiations and employeremployee relations.
\end{abstract}

Keywords : student migration, life course, gender, Peru, Switzerland

\section{Résumé}

S'appuyant sur une perspective de parcours de vie, cet article se concentre sur l'analyse des transistions entre une éducation transnationale et le monde du travail, qui montre en particulier l'interdépendance des trajectoires professionnelle et familiale dans un contexte

\footnotetext{
* Université Lausanne, Suisse.
} 
migratoire. Je me concentre sur la migration péruvienne pour étudier dans un établissement d'enseignement supérieur suisse puis pour la recherche d'un emploi sur le marché du travail suisse; et je les lie avec des configurations familiales transnationales. Je présente deux types de parcours de vie trouvés parmi les hommes et les femmes péruviens hautement qualifiés: la concordance ou la discordance entre les diplômes d'études et les conditions d'emploi actuelles. Bien que de nombreuses études aient mis l'accent sur les problèmes de validation des diplômes étrangers en tant que principal obstacle pour les étrangers hautement qualifiés, je démontre qu'être diplômé en Suisse ne garantit pas automatiquement un emploi convenable aux hommes et aux femmes péruviens en Suisse. Les résultats soulignent clairement le rôle ambivalent des diplômes suisses pour les migrants, ainsi que l'impact hétérogène de la vie en couple et de la parentalité. Ces processus peuvent s'expliquer par différentes opportunités et limitations basées sur les domaines de qualification et une normativité dynamique entre les sexes dans les négociations de couple et les relations employeur-employé.

Mots clés: étudiant immigrant, cursus, genre, Pérou, Suisse

\section{Introduction}

Drawing on a life-course perspective, this paper focuses on the analysis of the transnational education to employment transitions that particularly shows the interdependence of professional and family trajectories in a migration context. I focus on Peruvian migration to study in a Swiss Higher Education (HE) institution and subsequent job-hunting in the Swiss labour market; and link them with transnational family configurations. The focus is on assessing issues of interdependent live domains across places and moments and combining the analysis of skills and care circulation. I present two types of life-courses found among highly skilled Peruvian men and women: the concordance or discordance between international education credentials and current employment conditions. Although many studies have emphasised the problems of validating foreign degrees as the greatest barrier for highly skilled foreigners, I argue that having a Swiss degree does not automatically guarantee adequate employment for Peruvian men and women. In addition, the influence of family caregiving responsibilities on professional trajectories is not homogeneous. The findings clearly stress the ambivalent role of Swiss degrees for Peruvian men and women, as well as, 
the heterogeneous impact of partnership and parenthood. Before considering a dichotomization of careers based on gender too promptly, I explore gender normativity related to family and professional spheres. These processes can be explained by different opportunities and limitations based on fields of qualification and dynamic gender normativity in couple's negotiations and employer-employee relations.

In what follows, I first briefly review the debate on skills and care circulation by combining two frameworks: mobility of skills and transnational family. Then I present my case study: Peruvian migration and international students in Switzerland before discussing the two types of transnational education to employment transitions. Finally, I discuss three dimensions to explain these results.

\section{A life-course approach on international student migration: gender differentiation of professional and family trajectories}

The existing literature of international student migration is rather ambivalent as to the implications of interdependencies of professional and family trajectories; not least because the focus of attention varies considerably from one study to another. Studies on international student migration analyse the issues of labour market participation after graduation in the host country (Suter and Jandl 2008) or the role of spouses during the completion of the academic program abroad (Bordoloi 2015). Drawing on a life-course perspective, I propose to analyse both topics as events of international student's life-courses.

Drawing on the life-course approach, I consider transitions as changes in states, statuses and/or roles that are meaningful in particular trajectories and broader contexts (Alwin 2012). As one of the principles of this approach, the sequence of events and transitions displays the ways in which individual biographies interact with historical contexts and yield patterns of social pathways with multiple dimensions and directions (Alwin 2012; Elder and Giele 2009; Sapin, Spini, and Widmer 2014). Here, the analysis of transitions focuses on two live domains: professional and familial, and the ways in which the dynamics of gender norms at both 
spheres influenced changes in statuses. Based on the interdependence of live domains, education to employment transitions are analysed in relation to family trajectories. According to René Levy: "the complete biographical path of an individual is composed of a series of "parallel" trajectories: familial, relational, occupational, residential, etc." (Levy and Widmer 2013:17). Particularly, gender differentiation of life-courses focuses on the interdependence of family and employment trajectories: "it implies the dominant assignation of women to the family and of men to paid work" (Levy and Widmer 2013: 25). Gender differentiation of professional and family trajectories assesses different forms of institutionalization that vary from sex stereotypes, explicit or implicit normality assumptions in social policy to institutions framing our everyday life (Levy and Widmer 2013). In assessing the transnational education to employment transition, a dynamic approach to gender norms helps to understand continuity and changes of gender differentiation of professional and family trajectories. Considering norms as a symbolic and prescriptive element in social practice while taking into account "the steering dimension of their realization through time improve our understanding of the normativity realm, the specification of proper practice and the collective determination of the directions of life-courses" (Pearse and Connell 2015:7). Furthermore, the transnational dimension addresses the fact that these transitions happened across borders in (at least) two national settings in relation to migration experiences.

\section{International student mobility from non-EU countries in Switzerland: the case of Peruvian graduates}

In 2015/2016, $24.9 \%$ of Swiss university students were "foreigners" ${ }^{1}$, in the sense that they had obtained their secondary school-leaving diploma

1 "The term foreigner (living in Switzerland either temporarily or long term but not having Swiss citizenship), rather than immigrant (foreign-born) is used in Swiss legislation and statistics. This reflects a legal conception of citizenship based on the principle of descent rather than on place of birth" (Riaño et Baghadi, 2007: p. 164). Due to this rule, as direct descendants of at least one Swiss parent or grandparent, some Peruvian migrants actually have Swiss citizenship before moving to the country. 
outside of Switzerland, as compared to just $13.1 \%$ of students in 1990/ 91 (SFSO 2017b). The proportion of foreign students increases with degree level: foreign students at bachelor level represented $22 \%$ whereas at $\mathrm{PhD}$ level represented 52.1\% in 2010/2011 (Kunz 2011:7) and type of institutions where applied sciences and teaching universities show the lowest share: $12.5 \%$ and $5 \%$ in 2015/2016 (SFSO 2017b). Without considering PhD students, most of foreign students (74\%) come from neighbouring countries and other EU countries while $4 \%$ come from Central and South America (CSA) in 2012/2013 (Fischer and Gerhard Ortega 2015:11). Although CSA students in Switzerland represent a minority, their experiences challenge accepted ideas about international student mobility. Brain drain or gain is not a smooth circulation nor the "race for talent" between Northern countries guarantees a straightforward transition to labour market for newly foreign graduates from HE institutions in those countries. While their social background provides sufficient resources to embark in student migration to Switzerland, the Swiss migration regime might offset these privileges after graduation.

Establishing the importance and evolution of international student migration to Switzerland is no easy task, since the category "foreign students" includes people with very different life histories (Teichler 2015). In Switzerland, the literature has been particularly interested in the educational accomplishments of second-generation immigrants from European countries (Fibbi, Kaya, and Piguet 2003; Griga 2014), i.e. in non-mobile foreign students who have already lived and studied in their host/home country, rather than in non-EU foreigners who specifically move to Switzerland in order to study. The latter have to follow a long and often complex route into the country, via direct and selective admission procedures to a HE institution. Each HE institution is entitled to make its own decision concerning the entry regulations to particular courses and is free to recognise (or not) qualifications obtained abroad $^{2}$ (Guissé and Bolzman 2015). Once they have obtained a place at a HE institution, non-EU citizens also

2 In many cases, foreign students are admitted to enrol on the condition that they pass additional courses in advance of formal registration to the degree programme they want to follow. Once these "prerequisite" credits have been obtained, they follow the courses under the same conditions as Swiss and EU students. 
have to apply for a student visa. This involves providing the Swiss Embassy in their home country with a number of formal documents, including: a letter of acceptance to the study program, proof of economic solvency (the deposit of approx. 24,000 CHF in a bank account) and/or a letter of sponsorship from a Swiss citizen. This process is both costly and timeconsuming ${ }^{3}$. The Federal government also runs its own highly selective student mobility programmes, which provide a limited number of studentships to applicants from non-EU countries. It provides a monthly stipend of $2000 \mathrm{CHF}$ for a period of 3 years to a small number of "promising" $\mathrm{PhD}$ candidates from Asia, Africa or Latin America. Foreign students who pass through this selective route into the Swiss HE system are usually helped with the visa application process and are sometimes provided with subsidised student accommodation for the duration of their studies.

In 2015, Peru's National Office of Electoral Processes had 6,482 registered voters in Switzerland, while the Swiss Federal Statistical Office counted only 2,898 Peruvian citizens in $2015^{4}$ (SFSO 2016). Besides the fact that international student migration represents already an elite, Peruvian migration is a highly selective phenomenon. Compared to other well-documented cases of Latin American migrants, Peruvian migration shows high education attainment (Takenaka and Pren 2010). $29 \%$ and $10 \%$ of Peruvian migrants declared being university students and professionals between 1994-2009 (Paerregaard 2015). In addition, in 2007, more than $50 \%$ of Peruvian migrants belonged to middle classes and $26.3 \%$ belonged to the most privileged ones while only $20.7 \%$ of them belonged to the most impoverished groups (Sanchez 2012:85). Also, Peruvian migration has been female predominantly: $56.5 \%$ and $52.3 \%$ of Peruvian migrants were females between 1991-2000 and 2001-2005, respectively (Sanchez 2012:78). In fact, they represent an under-researched global trend: the feminization of highly skilled migration (Dumitru and Marfouk 2015). The focus on Peruvians graduates, a minority but highly selective group of migrants,

3 Some of our interviewees mentioned having to overcome passive or active resistance to their visa application procedures on the part of Embassy administrative staff.

4 Some Peruvians are not counted in Swiss statistics because they have double nationality from Switzerland or other European countries and Peruvians younger than 18 years old are not counted as voters. Neither undocumented Peruvians are identified in statistics easily. 
thus suits the aim of this research to explore transnational education to employment transition patterns that range from upward to downward social mobility and to understand the ways in which gender influences lifecourses. Indeed, Peruvian and Swiss gender regimes are characterized by the assignation of family care obligations mostly to women. It is important to stress the relatively differentiated gender regime that prevails in the Swiss context (Giraud and Lucas 2009), because the scarcity and cost of public childcare services hinders women's full-time, continuous labour market participation, particularly after the birth of a first child (Giudici and Gauthier 2009). It has been argued that highly skilled foreign women also struggle with the dominant "master status" (Krüger and Levy 2001) of the Swiss gender regime (Riaño 2011; Riaño and Baghdadi 2007).

The Swiss migration regime is generally recognised as being one of the most restrictive in Europe (Huddleston et al. 2011). Before the 1990s, Peruvian citizens did not need a visa to enter Switzerland. Likewise, before the 2008 Federal Act on Foreign Nationals imposed tighter restrictions on the ability of non-EU citizens to study, work or settle in the country, Peruvians had more opportunities to switch from a tourist visa to a student or work permit. Although non-EU foreign students do have access to student permits, these are only valid for the precise duration of their study programme. Up until 2011, non-EU foreign graduates were required to leave the country immediately after graduation. Since that date, a six month "job search extension" to student permits has been introduced (State Secretariat for Migration 2011). However, in order to be allowed to recruit a foreign graduate, employers are required to attest that the person in question is better qualified than any available Swiss or EU citizen (The Federal Council 2005), under a so-called "essential employment" clause ${ }^{5}$. Foreign graduates with Swiss qualifications need to find an employer who is willing to "sponsor" their work permit application, by attesting a shortage of equally qualified Swiss or EU candidates in the field. Several authors have noted that this

5 As for the student permit, work permits represent a conditional residence in Switzerland (permit B) for non-EU citizens. They renew their B permit each year by proving the fulfilment of the purpose of stay. However, the number of B permits allocated to workers is subject to quotas. Quotas for 2016: 4,000 for permit L and 2,500 for permit B (The Federal Council 2005). 
type of procedure tends to create a "gendered global hierarchy of professions", which considers male-dominated sectors such as finance and technology to be of "greater national interest for global competitiveness" than female-dominated sectors such as care work and welfare services (Kofman and Raghuram 2006:282-303). Accordingly, Peru and Switzerland HE systems show a gendered division of fields. In Peru's universities, male students are concentrated mostly $(27.8 \%)$ in engineering disciplines whereas female students are concentrated (20\%) in education in 2014 (INEI 2015). In Switzerland, women in engineering represent only $29.1 \%$ whereas they are $67.5 \%$ in social sciences and humanities (SSH) in 2015/2016. In addition, the part of foreigners is higher in the male-dominated disciplines ( $42.7 \%$ in engineering) than the female-dominated ones (24.8\% in SSH) (SFSO 2017a).

\section{Research methods}

Research findings are based on qualitative biographical interviews with LIVES life-calendars ${ }^{6}$ in order to collect important events of participant's professional and family trajectories, as well as, their own explanation of transitions. I conducted 54 interviews in Spanish with Peruvian men and women living in French and German speaking regions in Switzerland during 2014 - 2016. Contact with participants had been established through personal networks and immigrant associations; the first participants gave me names of other possible contacts ("snowball method"). Peruvian nationality was a selection criterion for participants, but those Peruvians with dual nationality were not excluded. For this article, I chose 19 participants ( 9 women and 10 men) since they had studied at a Swiss HE institution ${ }^{7}$ (Table 1).

6 A life-calendar is defined as «a two-way grid, with the temporal dimension on the one side, and different life domains on the other. Respondents are asked to report events for each life domain, relating them to what happened across other domains or in references to time landmarks. While filling in this calendar, respondents can visualize their life trajectory, linking what happened to when, where and for how long it happened» (Morselli, et al., 2013, p. 3). Biographical interviews and life-calendars assess three processes of life-course: diffusion, accumulation and interpretation (Morselli, et al., 2013).

7 Two interviewees (1 man +1 woman) had graduated from a University of Applied Sciences; nine ( 2 men +7 women) had studied at a University and five (all men) had graduated from one of the Federal Institute of Technology. 


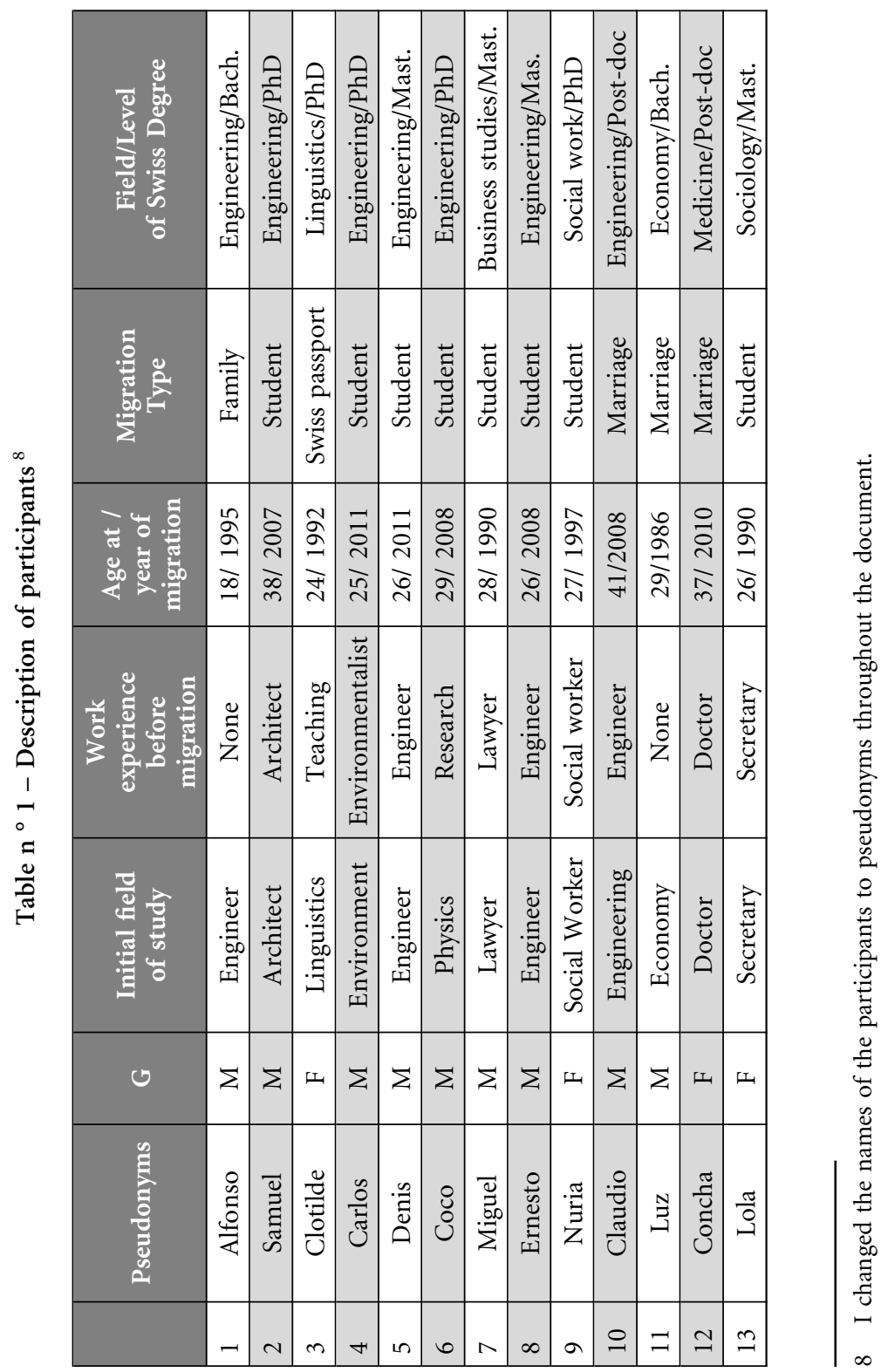




\begin{tabular}{|c|c|c|c|c|c|c|}
\hline 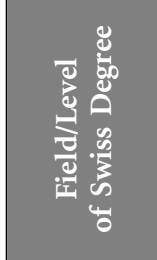 & 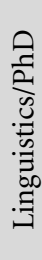 & 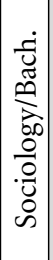 & 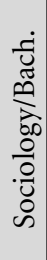 & 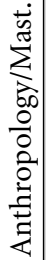 & 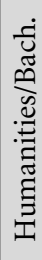 & 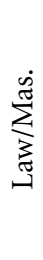 \\
\hline 总 & 䒕 & 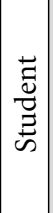 & 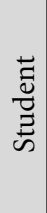 & 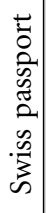 & 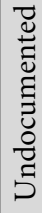 & 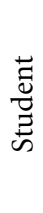 \\
\hline 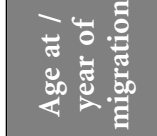 & 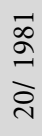 & $\begin{array}{l}\frac{2}{2} \\
\bar{\lambda} \\
\text { ป }\end{array}$ & 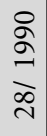 & $\begin{array}{c}\frac{1}{\sigma} \\
\stackrel{\sim}{2} \\
\frac{\pi}{m}\end{array}$ & 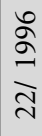 & 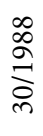 \\
\hline 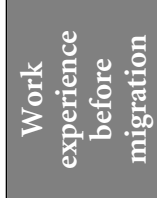 & $\begin{array}{l}\text { Еี } \\
\text { Z }\end{array}$ & 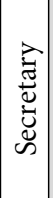 & 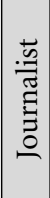 & 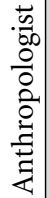 & $\begin{array}{l}\mathscr{Z} \\
\text { Z }\end{array}$ & 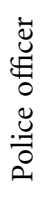 \\
\hline 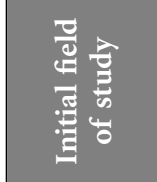 & 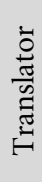 & $\begin{array}{l}\stackrel{0}{\Xi} \\
\text { Z }\end{array}$ & 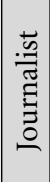 & 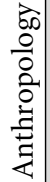 & 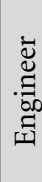 & 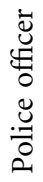 \\
\hline$\checkmark$ & 山 & $\omega$ & LI & $\Sigma$ & $\Sigma$ & $\Sigma$ \\
\hline \multirow[t]{2}{*}{ 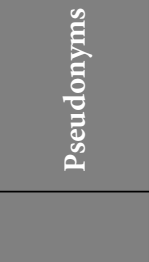 } & 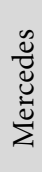 & $\stackrel{\stackrel{\mathbb{Z}}{\Xi}}{\stackrel{\Xi}{\Xi}}$ & $\begin{array}{l}\tilde{D} \\
\stackrel{2}{0}\end{array}$ & $\frac{\check{\Xi}}{\stackrel{\Xi}{\varpi}}$ & $\frac{\pi}{\widetilde{J}}$ & $\stackrel{\Xi}{\Xi}$ \\
\hline & $\Xi$ & $\stackrel{10}{2}$ & $\stackrel{0}{0}$ & ニ & $\stackrel{\infty}{-1}$ & $\curvearrowright$ \\
\hline
\end{tabular}


As Table $\mathrm{N}^{\mathrm{o}} 1$ presents, there are also differences between dates of arrival in the host country and current age that influences the comparison between life-stories. Consequently, I chose to compare two transitions, meaningful changes in statuses, that have been experienced by all participants across borders: from student to worker and from being single to be in a couple at destination. The focus on both transitions helped me to understand the ways in which the changes of status acquired meaning for each participant's individual trajectory against the backdrop of dynamic gender normativity in two national settings. In this sense, I consider the gender normativity in the family sphere in relation to caregiving but also in the professional sphere in relation to careers. For instance, the participants show a clear distinction based on fields of study; most of the men (7 out of 8) belong to Finances and Engineering and most of the women (7 out of 8 ) belong to Humanities and Social Sciences. There are different career paths for them: academia for the latter and private enterprises for the former. Careers in academia and private enterprises share some features. Work is flexible, which means that there is no limitation to office hours but "long work-hours culture, the presumption of "unlimited availability" combined with requirements to be geographically mobile and to manage tight deadlines" (Le Feuvre, 2015: 8-9. Internationalisation is important in both sectors.

\section{Transitions from the institutions in Peru to Switzerland, and from formation to employment in the host country}

Concordance/discordance between acquired qualifications across both countries and employment conditions is a criterion to compare participant's experiences. Those categories are extremes of a scale where I place all participants' experiences resulting in two types of transnational transitions from education to employment. While several paths may be linked within the empirical trajectory of a single individual, the ideal types represent paths that lead into high-level employment or outside the upper segments of the Swiss labour. The first type called "concordant" professional trajectories describes the experiences where a linear pattern 
occurred at both transitions: expected time to earn degrees in Swiss HE institutions and to find jobs adequate to skills. The second type named "discordant" professional trajectories refers to experiences where nonlinear patterns occurred: more time for finishing studies and finding jobs below qualification-level. In general, nine participants (6 men and 3 women) had a concordant professional trajectory. While other seven participants ( 2 men and 5 women) had a discordant trajectory. Before considering a straightforward dichotomization of careers based on gender, I present in more detail the influence of family configurations and caregiving responsibilities. Partnership and parenthood do not have a homogeneous impact.

\subsection{Concordant professional trajectories}

This path refers to Peruvian professionals that obtained a Swiss degree in the expected time and entered high-level employment almost immediately. A linear transition is characterized by financial aid, no visa and/or enrolment issues in Swiss HE institutions. Moreover, they evoked the "easiness" of their arrival and formation in the host country thanks to being part of an elite with previous high-quality education and privileged social origin in Peru. There is a feeling of being familiar with institutional cultures, courses exigencies and being abroad, which seems to foster continuity. The direct path seems primarily tied to a specific profession and a caregiving model of transnational families. A straightforward transnational transition for Peruvian men holding a Swiss degree in engineering and enjoying support from transnational family networks and spouses. Thanks to family's resources in Peru, these participants had already obtained foreign language training (English, German or French) and enjoyed remittances sent to Switzerland by parents in Peru.

If a person is unable to immediately enter the Swiss labour market after graduation, a preparatory stage accomplishes employment commensurate to skills. Specialization is a way to acquire skills related to the host country. For example, foreign language improvement, volunteer work in associations related to the professional domain or training in less skilled jobs. In my interview material, most of interviewees mention this path, but only nine reached the highest level of the Swiss labour market. One of them is Nuria a social worker. 


\section{Excerpt 1: a concordant professional trajectory for a Peruvian female social worker}

After earning her Bachelor degree as a social worker, Nuria worked for NGOs interested in women's health rights. Also, she had French courses in Peru. She won a scholarship to do a PhD in social work that included French courses before beginning the academic program. While doing her PhD about immigrants' health issues, she started to do volunteer work in associations related to the topic. She met her future husband and got married before finishing the PhD. Although she took more time than expected to obtain the diploma, she was offered paid employment in one association before graduation. Then she was offered a position as professor in a University of Applied Sciences where she works until now. Afterwards, her first child was born and she had 6 months of maternity leave. She also negotiated to re-enter gradually from a $20 \%$ occupation rate to an $80 \%$ rate, and her child entered the childcare facilities for university's employees. She shares with her husband hands-on caregiving and management of care services. She said that her family is pretty particular, since her husband, a chemist, had an irregular job, so she is the one with a more stable job and more than $80 \%$ occupation rate.

Transition to employment after obtaining a Swiss degree also involves coping with legal obstacles. In Nuria's case, family reunification meant a legal solution to improve her chances in the Swiss labour market. This solution entailed couple's caregiving negotiations. However, couple's negotiations do not always align to traditional family models. They are embedded in employment opportunities for each spouse in Switzerland. Measures for gender equality in academia might have a positive impact on women's employment after motherhood. Not only maternity leave and childcare services, but also negotiation with employers strengthens women's negotiation capacity in the couple. In contrast, the absence of employment-family measures on private enterprises affects Peruvian men caregiving responsibilities. In fact, some of them in the engineering and finance sectors complained about reduced paternity leaves, less flexible bosses and long-working hours. Since salaries are higher in these sectors, 
the female spouse diminishes her occupation rate after parenthood. Couple's negotiations seem to encourage the most promising career- that might belong to the Peruvian partner- and delegate caregiving responsibilities to the other spouse.

\subsection{Discordant professional trajectories}

Transnational transition from education to employment is discordant. Across the body of interviews, seven people experienced this type that is female-dominated and tied to specific fields: humanities and social sciences. Institutional support is scarcer than in the first type. Interviewees experienced problems to enrol in universities and finish the academic program. For instance: they struggle with validation of foreign degrees and adaption to new HE institutional environments. Validation of diplomas involved repeating years of study. Participants also evoked an "institutional shock" in adapting to Swiss HE institutions. They found important differences between institutional cultures. Indeed, they had studied in less prestigious HE institutions and had insufficient foreign language training. In addition, university fees and living expenses are covered by personal savings and precarious jobs predominantly.

Employment conditions do not improve with a Swiss degree and occupation rates tend to diminish with time. Indeed, these professional trajectories are characterized by part-time instable jobs that are not commensurate to their skills. For humanities and social sciences, options for academic careers are limited in Switzerland due to the small number of HE institutions. Transnational family configuration also had an impact. Although family reunification is a source of legal stability, couple's negotiations hinder Peruvian spouses' careers: caregiving responsibilities were delegated to them. Indeed, less promising employment conditions of the Peruvian spouse influenced couple's negotiations about whose career encourage and to whom delegate caregiving. Besides struggling with the Swiss care regime, they handle caregiving responsibilities while job searching, skills updating and/or working. Mercedes's life story is an example. 


\section{Excerpt 2: a discordant professional trajectory of a Peruvian female linguist}

Mercedes was studying Translation and Interpretation at the University. Her parents paid her a language training trip to Switzerland in 1981. She attended French courses and met her future husband. They got married and she struggled to enrolled in a Swiss university. Since her husband is Portuguese, she found it easier to finish her studies over there. She came back to Switzerland and obtained a Licence and Doctorate in Linguistics while working as a Spanish teacher and taking care of her first child. Problems in couple's negotiations resulted in divorce, but she started an academic career. Indeed, she obtained a professorship that would become tenured after three years. In the meanwhile, the university suffered an administration change towards a managerial culture and the rector closed Humanities sections due to the reduce number of enrolled students. Renewal of her contract as a Linguistic professor thus did not happened. Since then, she has fixed-term, part-time (less than $50 \%$ ) and unstable positions (on-call or upon request) as a lecturer. In the meantime, she got married again to a Swiss lawyer and had another child. She struggles to find employment commensurate to her skills due to scarcity of positions in Swiss universities and handles most of caregiving responsibilities at home.

Mercedes's experience shows the difficulties to achieve an academic career and to delegate caregiving responsibilities in transnational families. Due to conflicts with her ex-husband, she had to handle all caregiving responsibilities and advancement of her academic career. Re-marriage did not change this situation. The assessment of each partner's conditions in the labour market is important to decide who assumes caregiving within the couple. Other Peruvian graduates from Social Sciences had never performed a job related to their profession and worked less than $50 \%$. Peruvian graduates' less promising careers seem to reinforce their homemaker role. However, diversification is a coping practice with unemployment. They acquire other skills and do volunteering. 


\section{Conclusions}

Most of studies do not compare both upward and downward professional trajectories of international student migrants and gender differentiation within their life courses. The interdependence of family and professional trajectories shows two types of transition patterns: concordance and discordance between HE and employment in the host country. Indeed, Swiss degrees played an ambivalent role for employment amongst Peruvian graduates.

Achieving high-level employment depends on the field of study: maledominated professions such as engineering compared to female-dominated professions such as social sciences show contrasting results. There is a gendered differentiation of professional trajectories. Engineering and finances hold a privileged place in the global economy. The Swiss national economy favours these sectors and shelter many multinational enterprises. Humanities and social sciences are not as privileged in Swiss migration regimes and national economy. Also, these female-dominated fields are more related to academic careers where job positions are scarcer in this country. Pursuing an academic career has less chances of a linear pattern. However, gender equality measures and employee-employer negotiations in academia seem to have a positive result on Peruvian graduate's career.

Partnership and parenthood might hinder Peruvian female graduates' transition to employment. Couples can reinforce or defy gender traditional models in transnational families. Gender normativity related to employment affects couple's decisions. Gender norms are different across fields of qualification. Based on participant's experiences, gender equality is more visible in academic careers. Peruvian academic women evoked institutional settings with childcare services and superiors' support. These employment conditions might influence positively women's capacity to negotiate and share caregiving responsibilities with their husbands. In contrast, Peruvian male engineers and bank managers evoke norms of long-working hours, thus less time at home for hands-on caregiving. Provided their higher salaries, couple's negotiations resulted in the wife as the principal caregiver. There is an active construction of gender norms 
that create simultaneous dynamics of change and continuity (Pearse and Connell 2015). Interestingly, partner's employment opportunities are central to couple's negotiations, which is more related to gender norms in labour market than in the family.

Although the dates and age of arrival were heterogeneous in these group of international students, they showed two patterns of social mobility based on the comparison of key transitions in the family and professional spheres across borders. The dynamics of gender normativity in both spheres provide meaningful explanations for the bifurcation into upward and downward social mobility. Comparing upward and downward professional trajectories in a migration context underscore questions about accumulation of (dis)advantages. The two types show the accumulation of disadvantages or advantages (Schafer, Shippee, and Ferraro 2009). Although brain circulation is not a smooth process, international students mobilise resources based on social origin in the host country that facilitates the transition into Swiss HE institutions (e.g. being familiar with travelling abroad). Yet, the transitions into the Swiss labour market might cancel out these advantages based on the gender normativity in male and female-dominated careers.

\section{References}

Alwin, Duane F. 2012. Integrating Varieties of Life Course Concepts. 67:206-20.

Bordoloi, Samit Dipon. 2015. "i am standing still”: the impact of immigration regulations on the career aspirations of wives of international students in the USA. Journal of International Migration and Integration, 16:607-24.

Dumitru, Speranta and Abdeslam Marfouk. 2015. Existe-t-il une féminisation de la migration internationale? Féminisations de la migration qualifiée et invisibilité des diplômes. Hommes et Migrations, 1311(2):31-41.

Elder, Glen Jr. and Janet Giele. 2009. Life course studies. An evolving field. In The Craft of the lifecourse Research. New York: The Guilford Press, p. 1-24. 
Fibbi, Rosita, Bülent Kaya, and Etienne Piguet. 2003. Le Passeport ou le diplôme? Etude des discriminations à l'embauche des jeunes issus de la migration. Neuchâtel.

Fischer, Philipp and Sarah Gerhard Ortega. 2015. Les Étudiant-e-s internationaux dans les Hautes écoles Suisses. Neuchâtel: FSO.

Giraud, Olivier and Barbara Lucas. 2009. Le renouveau des régimes de genre en Allemagne et en Suisse: Bonjour "Néo Maternalisme"?. Cahiers Du Genre, 46(1):17-46.

Giudici, Francesco and Jacques-antoine Gauthier. 2009. Différentiation des trajectoires professionnelles liées à la transition à la parentalité en Suisse. Swiss Journal of Sociology, 35(2):253-78.

Griga, Dorit. 2014. Participation in higher education of youths with a migrant background in Switzerland. Swiss Journal of Sociology, 40(3):370-400.

Guissé, Ibrahima and Claudio Bolzman. 2015. Étudiants du sud et internationalisation des hautes écoles: entre illusions et espoirs. Genève: IES.

Huddleston, Thomas, Jan Niessen, Eadaoin Ni Chaoimh, and Emilie White. 2011. Migrant Integration Policy INDEX III. Suisse. Bruxelles.

INEI. 2015. Profesiones o Carreras Universitarias. In Peru: Indicadores de Educacion por Departamentos, 2004-2014. Lima: INEI, 113-24.

Kofman, Eleonore and Parvati Raghuram. 2006. Gender and global labour migrations: incorporating skilled workers. Antipode 38(2):282-303.

Krüger, Helga and René Levy. 2001. Linking life courses, work, and the family: theorizing a not so visible nexus between women and men. The Canadian Journal of Sociology 26(2):145-66.

Kunz, Barbara. 2011. Etudiants des Hautes écoles universitaires 2010/ 2011. Neuchâtel.

Levy, René and Eric D. Widmer. 2013. Gendered Life Courses between Standardization and Individualization. A European Approach Applied to Switzerland. Zurich/Berlin: LIT.

Paerregaard, Karsten. 2015. Return to Sender: The Moral Economy of Peru's Migrant Remittances. Oakland: University of California Press.

Pearse, Rebecca and Raewyn Connell. 2015. Gender norms and the economy: insights from social research. Feminist Economics 1-24.

Riaño, Yvonne. 2011. "he's the swiss citizen, i'm the foreign spouse": binational marriages and the impact of family-related migration policies 
on gender relations. In Gender, generations and the family in international migration. Amsterdam: Amsterdam University Press, p. 265-82.

Riaño, Yvonne and Nadia Baghdadi. 2007. Understanding the labour market participation of skilled immigrant women in switzerland: the interplay of class, ethnicity, and gender. Journal of International Migration and Integration / Revue de l'integration et de La Migration Internationale, 8(2):163-83.

Sanchez, Anibal. 2012. Perfil Migratorio Del Perú 2012. Lima: Organización Internacional para las Migraciones (OIM).

Sapin, Marlène, Dario Spini, and Eric Widmer. 2014. Les parcours de vie. De l'adolescente au grand âge. Lausanne: Presses polytechniques et universitaires romandes.

Schafer, Markus, Tetyana Shippee, and Kenneth Ferraro. 2009. When does disadvantage not accumulate? Toward a sociological conceptualization of resilence. Swiss Journal of Sociology 35(2):231-54.

SFSO. 2016. Population résidante selon année, type de population, sexe et nationalité (continent). STAT-TAB. Retrieved June 27, 2016 (https:// www.pxweb.bfs.admin.ch/Table.aspx?layout=tableViewLayout2\&px_ta bleid=px-x-0103010000_203 \%255cpx-x-0103010000_203.px\&px_lang uage $=$ fr\&px_type $=P X \& p x \_d b=p x-x-0103010000 \_203 \& r x i d=14 d 82763-$ 4354-4bbb-986 -f0da97200b61).

SFSO. 2017a. Students. Tertiary Education - Higher Education Institutions. SFSO. 2017b. Tertiary Education - Higher Education Institutions. Retrieved January 3, 2017 (https://www.bfs.admin.ch/bfs/fr/home/statistiques/education-science/personnes-formation/degre-tertiaire-hautesecoles.html).

State Secretariat for Migration. 2011. Foreign Graduates Holding a Swiss University-Level Diploma to Be Granted Easier Access to the Labor Market. Retrieved January 3, 2017 (https://www.sem.admin.ch/sem/en/ home/themen/arbeit/nicht-eu_efta-angehoerige/hochschulabgaenger.html).

Suter, Brigitte and Michael Jandl. 2008. Train and retain: national and regional policies to promote the settlement of foreign graduates in knowledge economies. Journal of International Migration and Integration 9(4):401-18. 
Takenaka, Ayumi and Karen A. Pren. 2010. Determinants of emigration: comparing migrants' selectivity from peru and mexico. The ANNALS of the American Academy of Political and Social Science 630(July):178-93. Teichler, Ulrich. 2015. Academic mobility and migration: what we know and what we do not know. European Review 23(S1):S6-37.

The Federal Council (2005). 142.20 Federal Act on Foreign Nationals. Retrieved January 3, 2017 (https://www.admin.ch/opc/en/classifiedcompilation/20020232/index.html). 